\section{En dements dagbok}

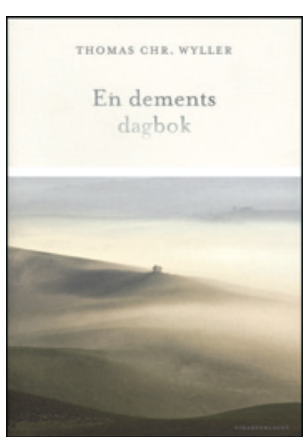

Thomas Chr. Wyller

En dements dagbok

221 s. Oslo: Vidarforlaget, 2013. Pris NOK 269 ISBN 978-82-7990-139-6

Dagboken begynner med forfatterens flytur. Han har vært borte et par uker og forsøker å mane frem bildet av hjemmet sitt for sitt indre øye. Men noe rimer ikke helt med hva han ventet å finne. Noe er kjent, noe bare synes kjent. Endelig begynner det å bli klart for ham: Det han ville se for seg, var hans nåværende hjem, mens det han hadde funnet, var barndommens. Han begynner å spørre seg selv om hvordan dette kan ha skjedd, og hvordan kan han vite at han har glemt noe - og hva er glemsel? Han bestemmer seg for å skrive en bok som skal hete En dements dagbok. Og det gjorde han.

Den første datoen er 20.9.2010, siste er 5.1.2012, og så er det en epilog fra 15.1.2012 der han setter endelig punktum. Han døde kort før han kunne ha feiret sin 90-årsdag høsten 2012. Hans sønn. Torgeir Bruun Wyller, skriver i forordet at det etter hvert ble behov for en del redigering av innholdet for å unngå gjentakelser, men teksten var helt og fullt forfatterens egen.

Ingen vil tvile på at teksten er Wyllers egen. Den er finslipt, nyansert, presis og malende. Han var en ordets mester i sitt vitenskapelige arbeid, og det gjenfinner vi i hans fortelling. Det forbløffende er at stilen holder seg uforandret gjennom hele sykdomsperioden, også når han skriver om sine mest smertefulle opplevelser. Et viktig tema er tristheten og voldsomme, utmattende gråteanfall. Han undrer seg over om dette er noe som samvarierer med demenstilstanden som en del av sykdommen, ikke som en reaksjon på den. Skiftningene kan også gå i motsatt retning der han plutselig er i glitrende humør, synger ungdomsviser uten problemer og spiller bridge som en ekspert. Det er aldri mulig å vite når vekslingene inntrer.

Han interesserer seg for ytre hendelser, finanskrise, kommunevalg som var et av hans forskningstemaer - og han reflekterer over 22. juli og drar linjene til holocaust og sin egen fangetid på Grini. Drømmene er ofte voldsomme. Av og til tenker jeg at han kanskje blottstiller seg for mye, men han lar det stå til, alt skal beskrives for kanskje å forstå en sammenheng. Han vil vite. Han leser at demente ofte har varme og kjærlige tanker for kjæledyr. Wyller har aldri vært interessert $i$ hunder, men så skaffer familien seg en, og til sin store undring opplever han at han synes hunden kan være ganske uimotståelig.

Det er en nær sammenheng mellom hans fysiske og psykiske helse, og i lange perioder orker han ingenting, heller ikke å skrive dagbok. Men når han orker, gir han oss en fantastisk gave. Det er vanskelig å forestille seg hvilken kraftanstrengelse dette må ha vært. Sjelden har en bok berørt meg så sterkt.

I avslutningskapitlet skriver han: «Min diagnose er likevel nogenlunde klar. Jeg er ikke blitt mer dement enn jeg var. Snarere tvert imot.» Og han tilskriver denne utviklingen blant annet: «Den omsorgen jeg møter og har møtt fra mine nærmeste, samt den livsmotivasjon dette har skapt i mitt sinn.»

Dette kan stå som en oppsummering og oppfordring til oss alle.

\section{Lettfordøyelig om vårt viktigste organ}

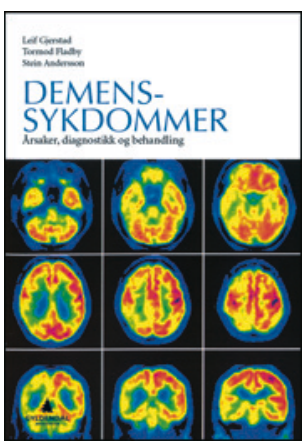

\author{
Leif Gjerstad, Tormod Fladby, \\ Stein Andersson \\ Demenssykdommer
}

Årsaker, diagnostikk og behandling.

235 s, tab, ill. Oslo: Gyldendal Akademisk,

2013. Pris NOK 385

ISBN 978-82-05-44993-0

$\AA$ forstå hvordan hjernen fungerer er i vinden. Hva gjør at en lege eller psykolog vurderer eller tenker på demens hos en pasient? Hos en pasient $i$ et sent stadium av en hvilken som helst type av demens, er det lett å se at hjernen til vedkommende ikke fungerer. Men når ble egentlig personen demenssyk, og hva er årsaken til de sykelige endringene som skjer i hjernen?

Dette og mange andre grunnleggende spørsmål om den trinnvise utviklingen av demens og kognitiv svikt gir boken fine svar på. Forskere ønsker ikke kun å vite hvordan en nervecelle kommuniserer med en annen, men også hvor denne overføringen av nervesignaler skjer, og hva lokalisering i hjernen betyr i forhold til ulike kognitive funksjoner som språk, hukommelse, eksekutiv funksjon og apraksi. Her blir hvert av områdene grundig forklart.

Forfatterne forklarer lettfattelig omkring temaer som mentale forandringer som ikke er forårsaket av demens, hvordan vurdere differensialdiagnoser, forebyggende behandling, nødvendige undersøkelser av personer rammet av demens, juridiske aspekter og pårørendes situasjon. De dekker nær sagt alle aspekter rundt demens på en sober måte uten å kaste seg på trenden til hjernereduksjonisme, og de forklarer omfattende begreper ut fra et naturlig klinisk ståsted.

En annen styrke er innholdet om de mest vanlige formene for demens: Alzheimers sykdom, frontotemporal demens, demens med lewylegemer, Parkinsons sykdom og vaskulær demens. Oversiktlig tabeller og flere gode illustrasjoner gjør at leseren gjennomgående får lett tak i fagstoffet. På slutten av hvert kapittel er det en nyttig og pedagogisk fin oppsummering. Sammendraget gjør at man enkelt kan repetere hovedpoengene.

Kapitlet om fremtidsperspektiver understreker at forfatterne har reflektert over hva vi vet i dag om demens, og hva vi kan håpe på i fremtiden. Det var forfriskende å lese. Det eneste jeg fant som jeg var direkte uenig i, var antall nerveceller som hjernen består av, konstatert i det første kapitlet.

Jeg kan anbefale boken til alle leger og annet helsepersonell innen demensfeltet, i tillegg til medisinstudenter og mer generelt til alle som ønsker en grundig og lettfordøyelig innføring $\mathrm{i}$ hva som skjer når hjernen ikke fungerer som før.

\section{Tor Atle Rosness}

Tidsskriftet 